\title{
Additive Manufacturing of Stamping Tools for Appliances
}

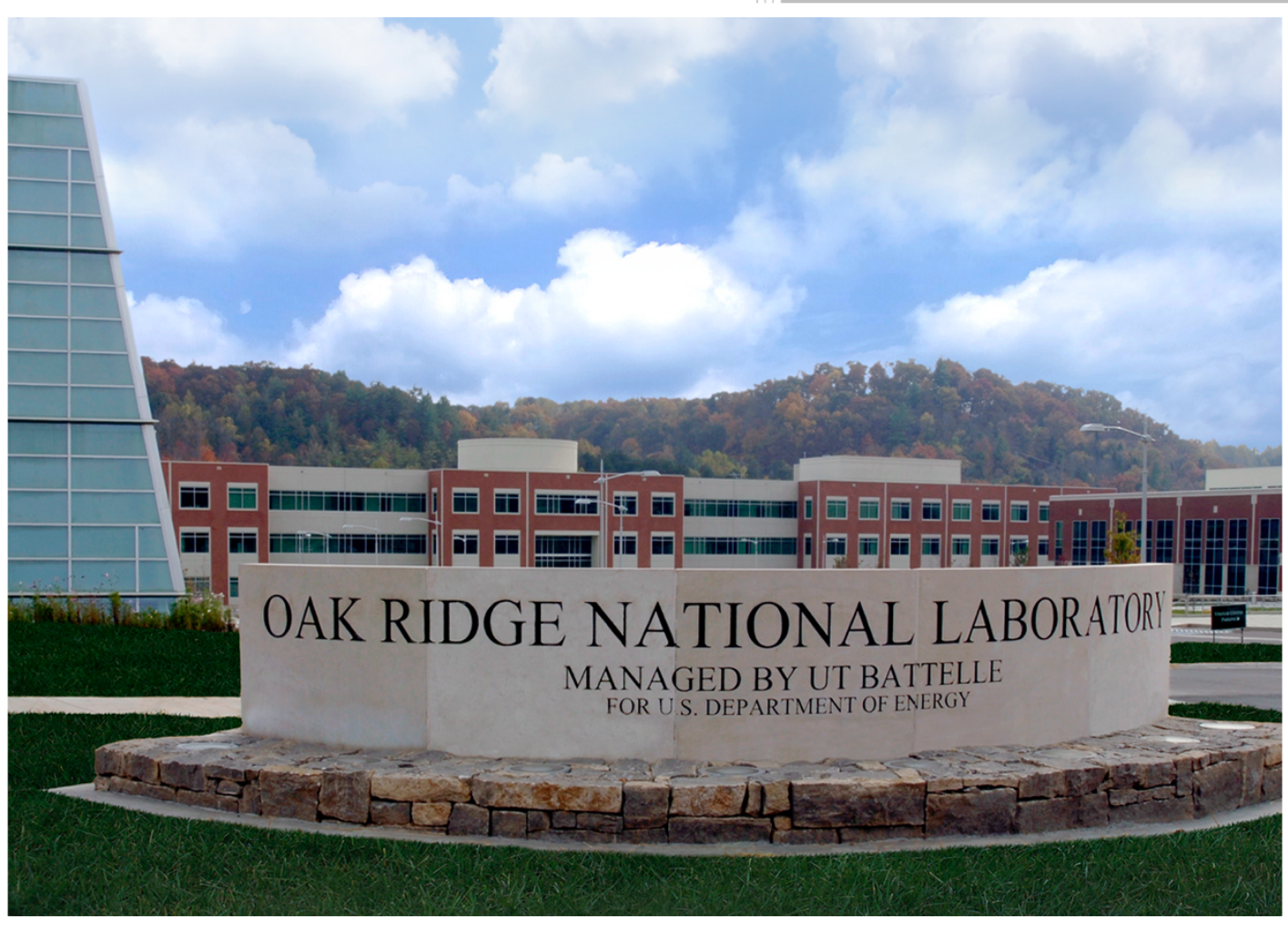

Brian Post (PI) Mark W Noakes Andrzej Nycz

May 31, 2020

CRADA FINAL REPORT NFE-19-07560

Approved for Public Release. Distribution is Unlimited. 


\title{
DOCUMENT AVAILABILITY
}

Reports produced after January 1, 1996, are generally available free via US Department of Energy (DOE) SciTech Connect.

Website www.osti.gov

Reports produced before January 1, 1996, may be purchased by members of the public from the following source:

\author{
National Technical Information Service \\ 5285 Port Royal Road \\ Springfield, VA 22161 \\ Telephone 703-605-6000 (1-800-553-6847) \\ TDD 703-487-4639 \\ Fax 703-605-6900 \\ E-mail info@ntis.gov \\ Website http://classic.ntis.gov/
}

Reports are available to DOE employees, DOE contractors, Energy Technology Data Exchange representatives, and International Nuclear Information System representatives from the following source:

Office of Scientific and Technical Information

PO Box 62

Oak Ridge, TN 37831

Telephone 865-576-8401

Fax 865-576-5728

E-mail reports@osti.gov

Website http://www.osti.gov/contact.html

\begin{abstract}
This report was prepared as an account of work sponsored by an agency of the United States Government. Neither the United States Government nor any agency thereof, nor any of their employees, makes any warranty, express or implied, or assumes any legal liability or responsibility for the accuracy, completeness, or usefulness of any information, apparatus, product, or process disclosed, or represents that its use would not infringe privately owned rights. Reference herein to any specific commercial product, process, or service by trade name, trademark, manufacturer, or otherwise, does not necessarily constitute or imply its endorsement, recommendation, or favoring by the United States Government or any agency thereof. The views and opinions of authors expressed herein do not necessarily state or reflect those of the United States Government or any agency thereof.
\end{abstract}


ORNL/TM-2020/1559

CRADA/NFE-19-07560

Energy \& Transportation Sciences Division

Advanced Manufacturing Office

\title{
ADDITIVE MANUFACTURING OF STAMPING TOOLS FOR APPLIANCES
}

\author{
Authors \\ Brian Post (PI) \\ Mark W Noakes \\ Andrzej Nycz \\ Date Published: \\ May 2020 \\ Prepared by \\ OAK RIDGE NATIONAL LABORATORY \\ Oak Ridge, Tennessee 37831-6283 \\ managed by \\ UT-BATTELLE, LLC \\ for the \\ US DEPARTMENT OF ENERGY \\ under contract DE-AC05-00OR22725
}

Approved For Public Release 



\section{CONTENTS}

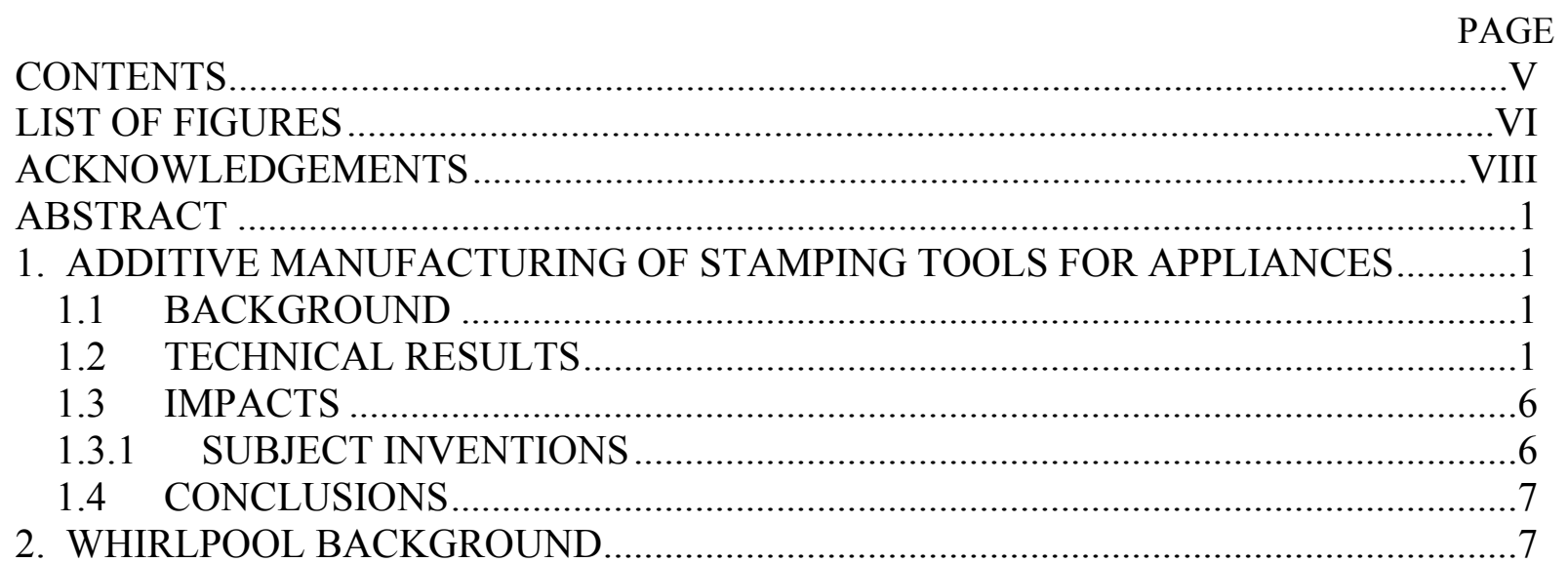




\section{LIST OF FIGURES}

Figure 1. As-printed CAD, as-printed overlaid on as machined CAD, and as-machined part

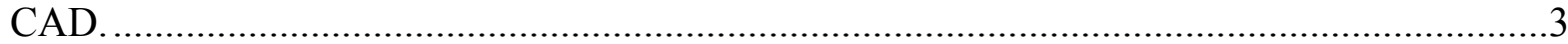

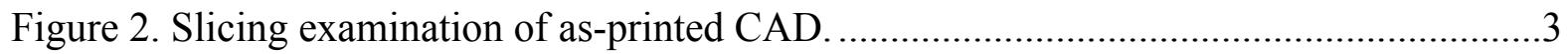

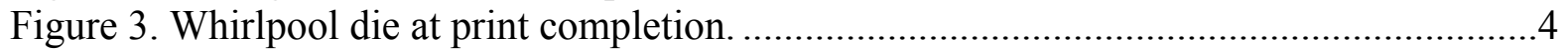

Figure 4. Printed Whirlpool die after machining and nitriding. .............................................

Figure 5. Chelar Industries stamping press used for demonstration........................................5

Figure 6. Stamped steel sheet metal components. …………...............................................

Figure 7. Part application for stove top. ........................................................................ 


\section{ACKNOWLEDGEMENTS}

This CRADA NFE-19-07560 was conducted as a Technical Collaboration project within the Oak Ridge National Laboratory (ORNL) Manufacturing Demonstration Facility (MDF) sponsored by the US Department of Energy Advanced Manufacturing Office (CPS Agreement Number 24761).

Opportunities for MDF technical collaborations are listed in the announcement "Manufacturing Demonstration Facility Technology Collaborations for US Manufacturers in Advanced

Manufacturing and Materials Technologies" posted at http:/web.ornl.gov/sci/manufacturing/docs/FBO-ORNL-MDF-2013-2.pdf. The goal of technical collaborations is to engage industry partners to participate in short-term, collaborative projects within the Manufacturing Demonstration Facility (MDF) to assess applicability and of new energy efficient manufacturing technologies. Research sponsored by the U.S. Department of Energy, Office of Energy Efficiency and Renewable Energy, Advanced Manufacturing Office, under contract DE-AC0500OR22725 with UT-Battelle, LLC. 


\begin{abstract}
Oak Ridge National Laboratory (ORNL) worked with Whirlpool Corporation to demonstrate additive manufacturing (AM) of stamping dies for the appliance industry using a large-scale wire arc metal additive manufacturing system jointly developed between Lincoln Electric and ORNL. An appliance stamping die was successfully printed, machined, nitrided, and demonstrated in the last quarter of 2019.
\end{abstract}

\title{
1. ADDITIVE MANUFACTURING OF STAMPING TOOLS FOR APPLIANCES
}

This phase 1 technical collaboration project (MDF-TC-2019-146) began on November 26, 2018 and concluded on May 31, 2020. The collaboration partner Whirlpool Corporation is a large business. An appliance stamping die was successfully printed, machined, nitrided, and demonstrated in the last quarter of 2019.

\subsection{BACKGROUND}

The primary objective of this project was to leverage ORNL additive manufacturing capabilities to develop stamping tools for production of components for the appliance industry. Whirlpool Corporation is a major producer of home appliances. The project targeted tools for the manufacture of sheet metal components for ovens and ranges. The key project goal was to elucidate the path forward and to examine the potential to reduce product lead and development timelines in the manufacture of sheet metal stamping dies, and to examine ways to reduce tooling weight and costs.

Sheet metal fabrication requires the use of high tonnage presses and high strength steel tools and dies. The lead time and capital required to fabricate these tools prevents rapid design iterations during early design phases, and often locks critical part parameters months before the product is launched. Late design changes from prototype and simulation activities drive high cost rework and schedule delays as tools must be relocated for rework. Due to the size and weight of the tools, installation, removal and shipping are costly in time and resources. Appliances use light gage sheet metal for most components, but the tools remain expensive and heavy. The lifetime and cycle requirements exceed those of automotive stamping, but the tool wear and overall tool size are lower, making this project a good stepping stone to larger stamping tools.

\subsection{TECHNICAL RESULTS}

The majority of this technical work was completed in Q4 FY2019 and Q1 FY2020 with design collaboration with Whirlpool and printing completed in FY2019, and with machining, nitriding, and testing occurring in FY2020. The tool was successfully tested on a research stamping press at Chelar Industries, a company that Whirlpool uses for machining and testing of prototype stamping dies. Forty range stove top parts were stamped to verify functional capability and part quality. The stamping die was not installed in Whirlpool's production assembly line due to changes in the final product design after the techcollab design was finalized and while fabrication was already in process. However prior testing of the small modular stamping die by Whirlpool validated the ability to go to high production quantities with AM stamping dies. Therefore the stamping die life should be significantly better with nitriding. 
Whirlpool and ORNL agreed to print the Phase 1 stamping die using 410 stainless steel (410SS) for the working surfaces while using mild steel where it could be used. Mild steel welding wire is substantially cheaper than 410SS wire so the use of mild steel where practical can lower the overall cost of the stamping die. Whirlpool requested a hardened stamping surface, but ORNL had not yet moved into the printing of tool steels. Therefore the decision was made to have the working surface of the die plasma nitrided for increased hardness. The use of tool steels in stamping dies is the ultimate goal; however, nitriding of softer materials has proven to be a reasonable alternative.

After a broad study of possibilities, two implementation options were selected for further study. Option 1 used a 410SS front (working surface) with a flat/solid mild steel back. Option 2 used a 410SS front with a ribbed mild steel back to save weight. Design considerations included:

- Die must produce quality usable parts.

- Die must survive use in a 250 ton stamping press.

- The finished die must be lighter than $235 \mathrm{lb}$.

- The die should be multi-material.

- Material savings should be part of the study/demonstration.

Whirlpool also worked a traditionally implemented stamping die in parallel for this task. The machined part required a tool steel billet weighing $325 \mathrm{lb}$ to produce a final tool weighing $234 \mathrm{lb}$. Option 1 produced a stamping die weighing $229 \mathrm{lb}$ with a minor weight savings of $5 \mathrm{lb}$. However the weight of the as-printed build would be $240 \mathrm{lb}$ which was a $84 \mathrm{lb}$ savings over the weight of the tool steel billet. Option 2 produced a machined weight of $200 \mathrm{lb}$ with a more substantial weight savings over than of the original tool of $34 \mathrm{lb}$ and a savings of $89 \mathrm{lb}$ of the as-printed part over that of the original tool steel billet. However the extra complexity and time required for printing and machining of the ribbed back was deemed unnecessary. Option 1 was selected.

The design process for the printed die involved modeling the finished part as machined, modeling the part as-printed to accomdate printing requirements such as permissible print overhangs $\left(15^{\circ}\right.$ was chosen for this part), bead widths and heights, overbuild to permit machining down to clean material, etc., and then slicing the as-printed part to identify any issues with the build geometry. The design process is therefore iterative. Figure 1 shows the as-printed computer-aided design (CAD) along with the as-machined $\mathrm{CAD}$, and an overlay of the as-printed $\mathrm{CAD}$ on the final machined part CAD. Figure 2 shows slicing exercises on the to-be-printed CAD. Figure 3 shows the die at completion of printing. Figure 4 shows the printed die following machining and plasma nitriding.

The plasma nitriding process was conducted after machining of the stamping die. The plasma nitriding process was run for a period of $36 \mathrm{~h}$. A nitriding depth (case hardening depth) of greater than $120 \mu \mathrm{m}$ was achieved. Typical hardness numbers of $75 \mathrm{HRc}$ were achieved. The cost to conduct nitriding of the die and a series of sample squares used for process post analysis to verify hardness was $\$ 1920$. Whirlpool did not share machining and testing cost data so it is not published here.

Testing was completed at Chelar Industries in November 2019. Figure 5 shows the stamping press. Forty samples were run on the development press at Chelar. The parts were examined for defects and found to be satisfactory for use. Figure 6 shows stamped sample parts. Figure 7 shows the part as it would be applied to the stove top. As previously mentioned, the printed stamping die was not installed on the actual Whirlpool production line due to design changes that would have required reprinting, machining, and nitriding which was outside of the scope of the Phase 1 funding. However, Whirlpool previously tested a small modular printed 410SS die that was neither heat treated nor nitrided for hardness, and the die produced approximately 78,000 parts before being removed from 
operation. Heat treating and/or nitriding would have greatly enhanced die lifetime.

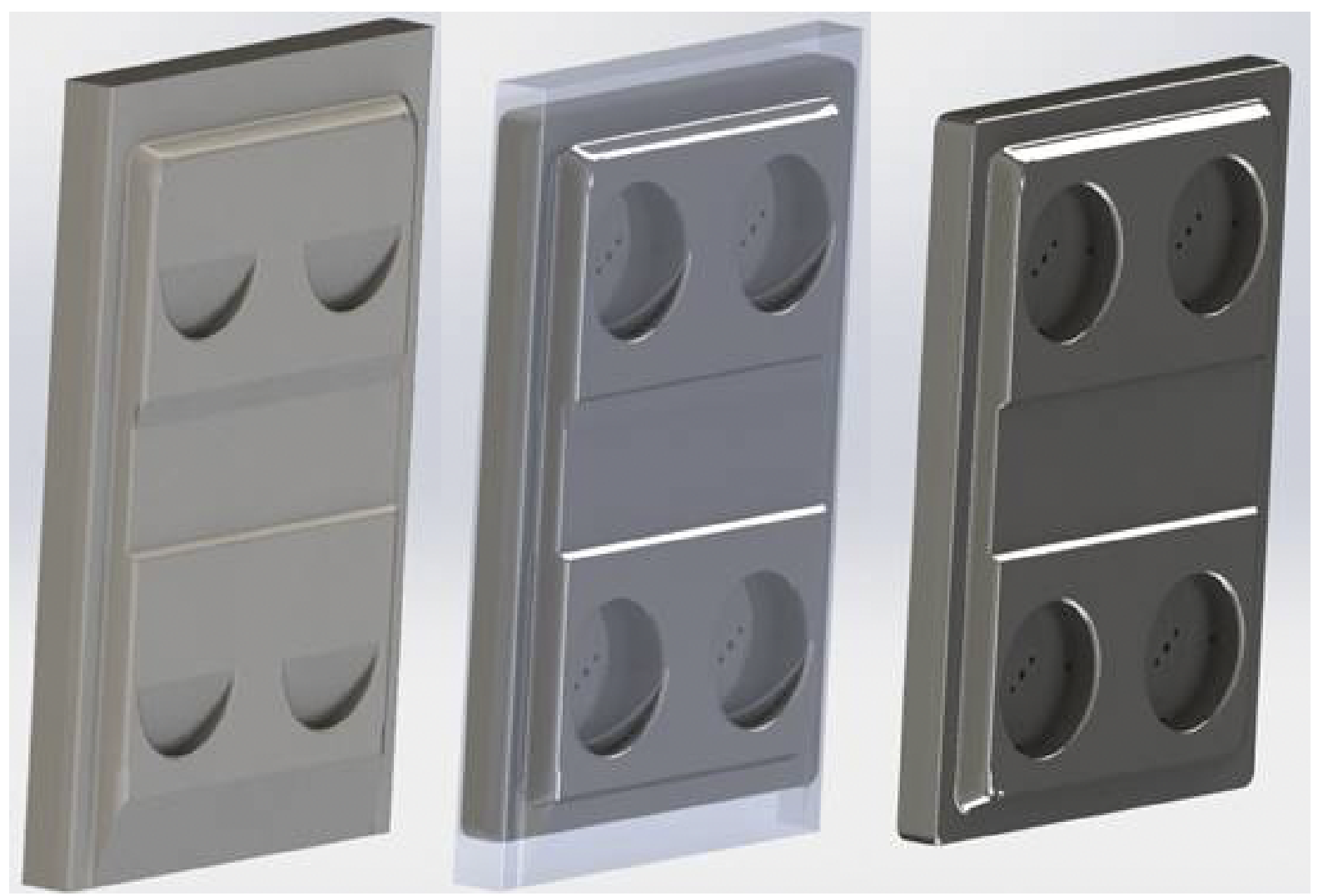

Figure 1. As-printed CAD, as-printed overlaid on as machined CAD, and as-machined part CAD.

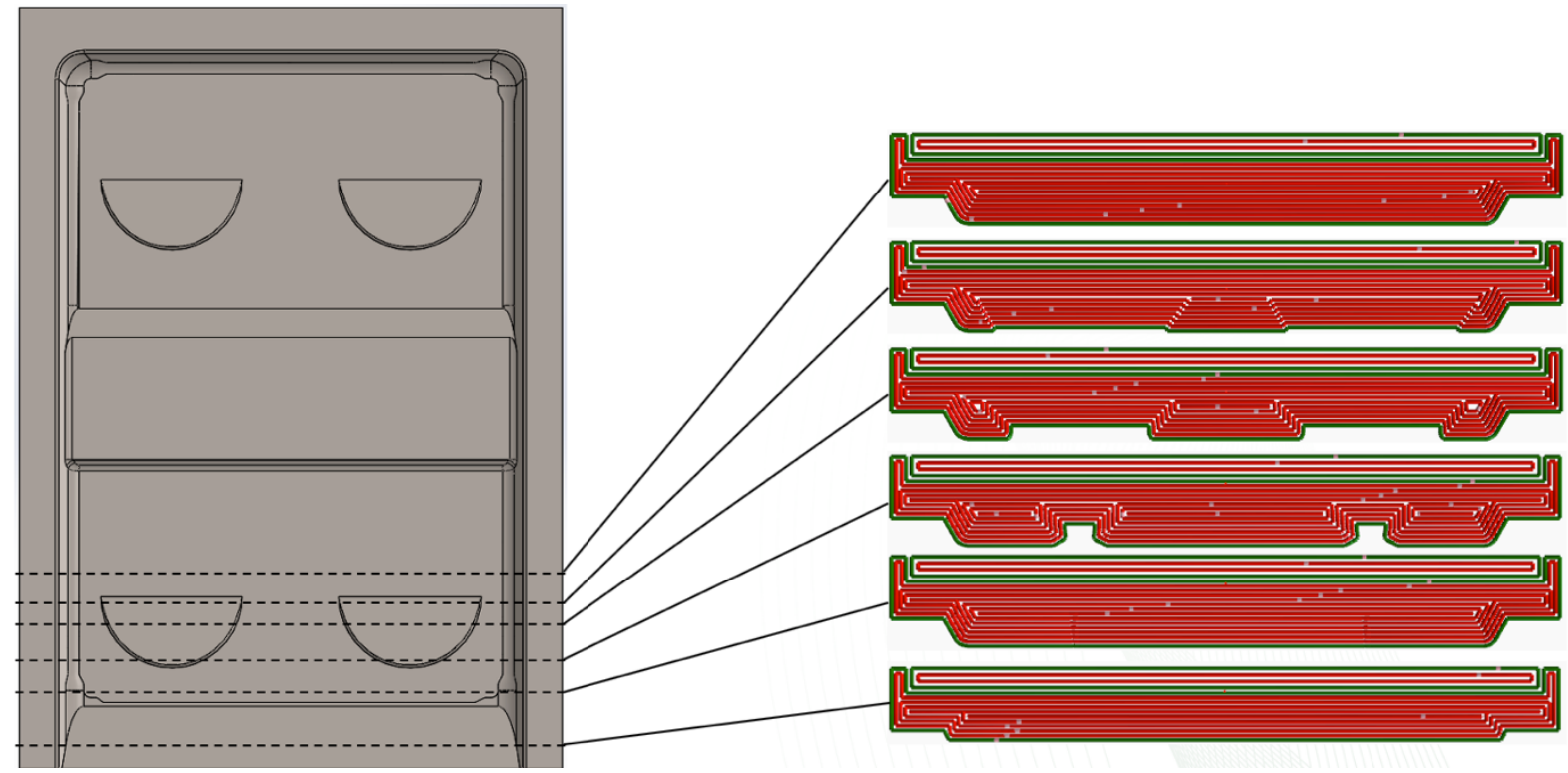

Figure 2. Slicing examination of as-printed CAD. 


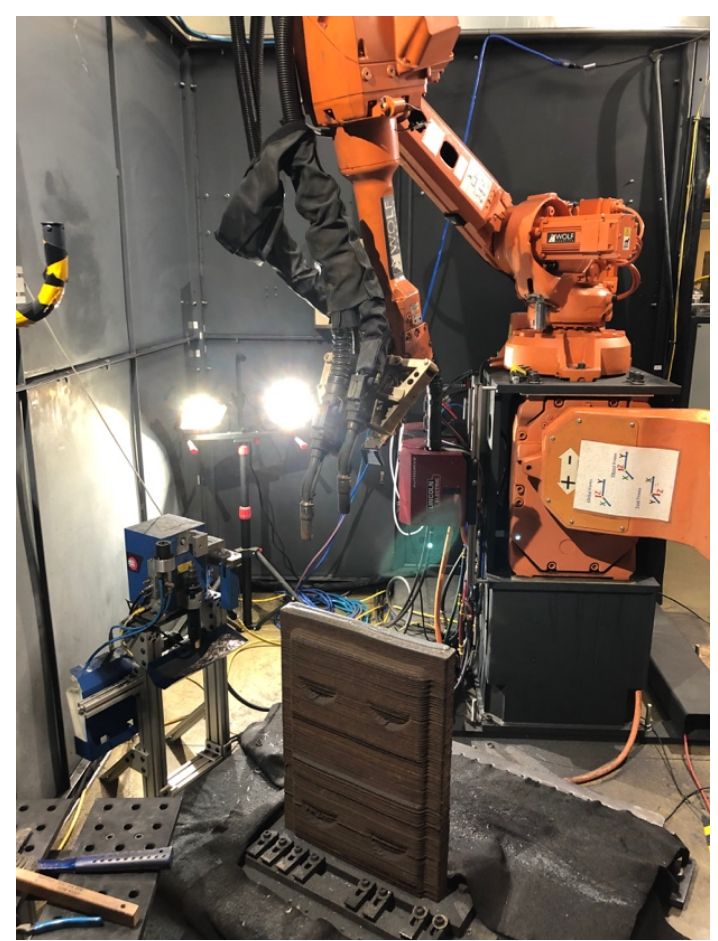

Figure 3. Whirlpool die at print completion.

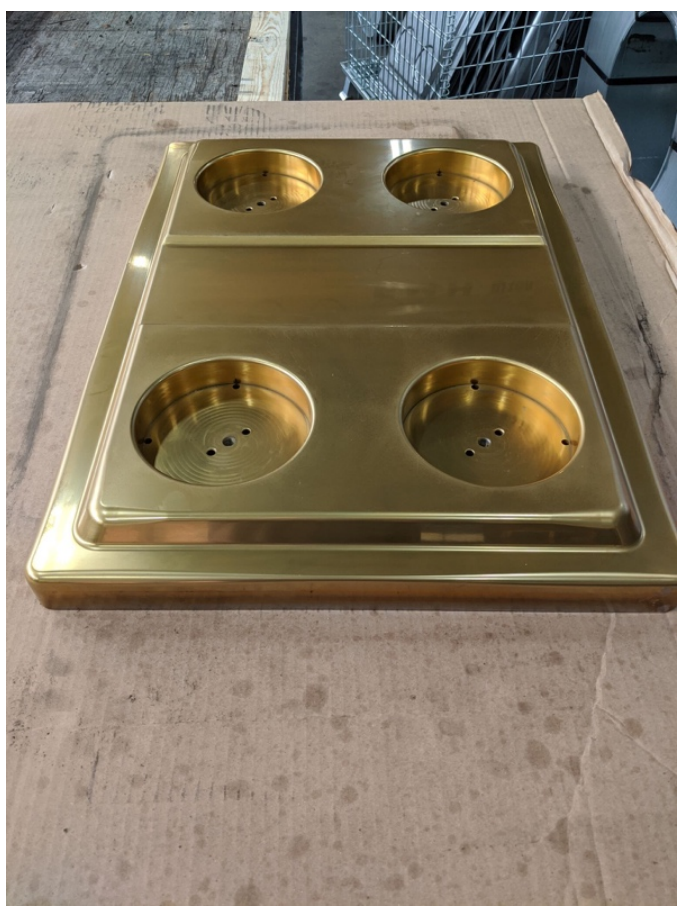

Figure 4. Printed Whirlpool die after machining and nitriding. 


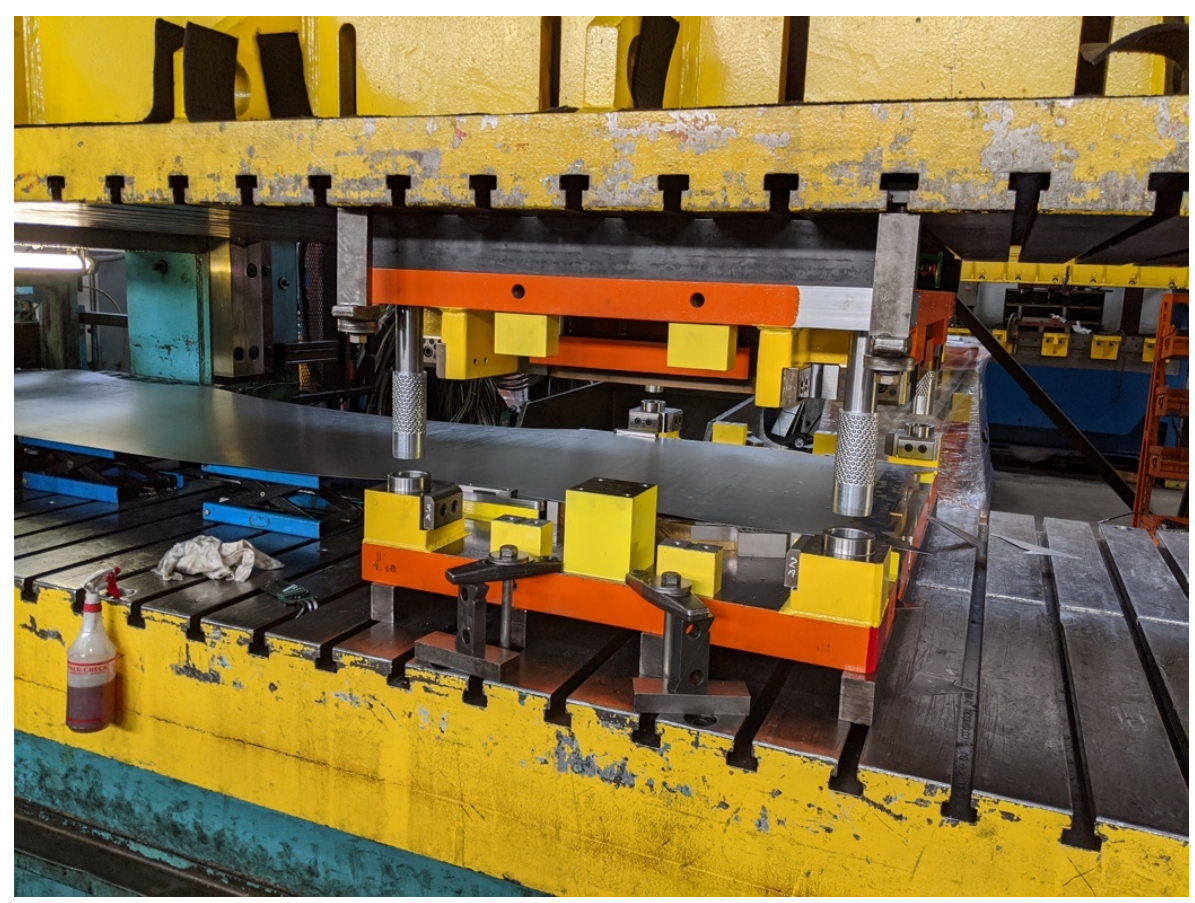

Figure 5. Chelar Industries stamping press used for demonstration.

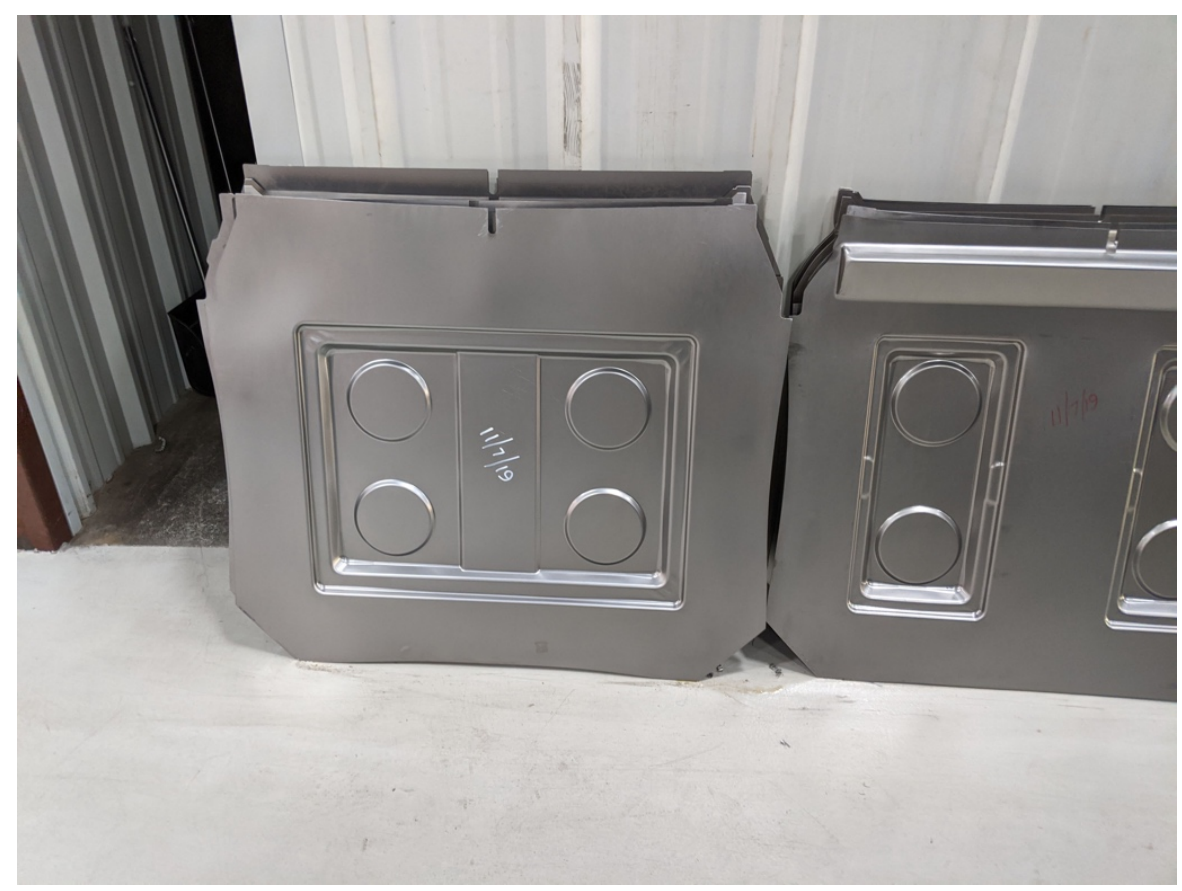

Figure 6. Stamped steel sheet metal components. 


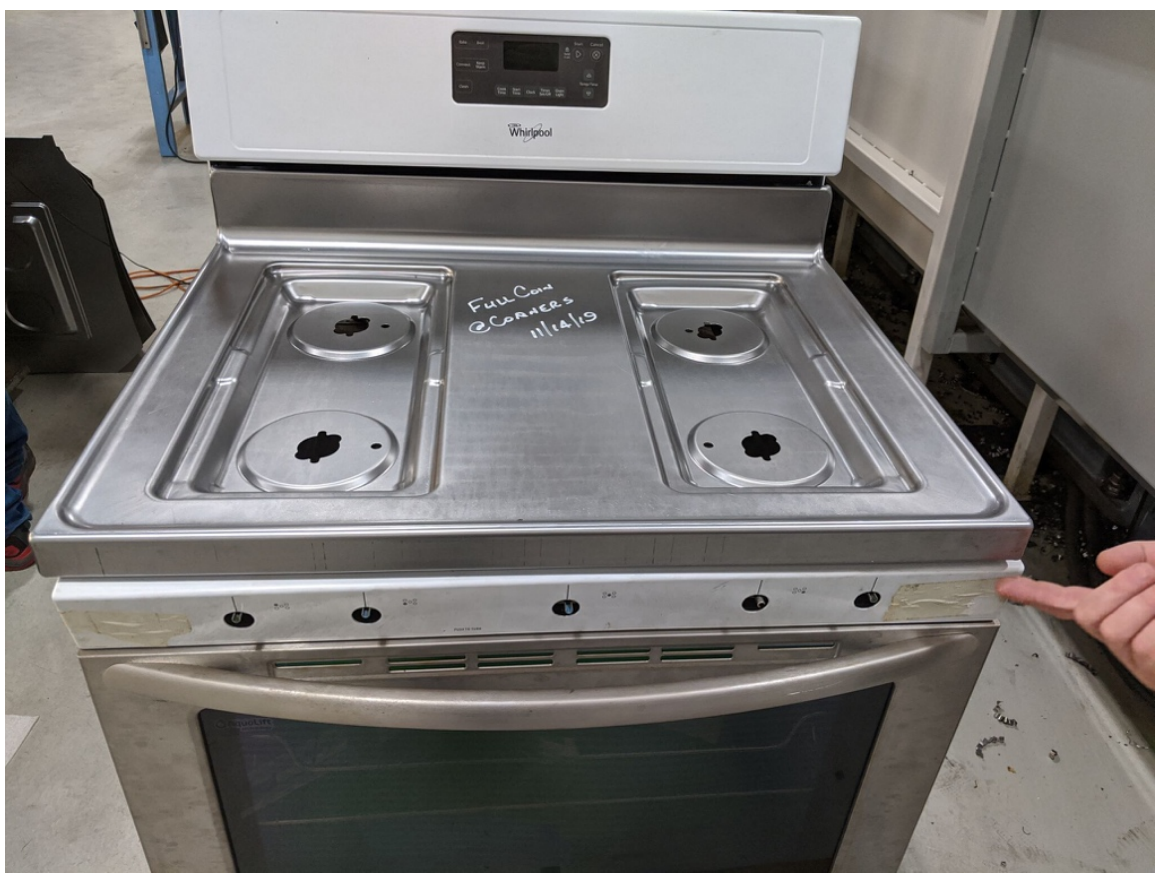

Figure 7. Part application for stove top.

There were substantial lessons learned as a part of this project that will assist further development of the technology. Whirlpool was very specific in the stamping die that they wanted to use for Phase 1 . The finished die was less than three inches thick. This did not allow a series of outer beads in one material with an infill in a separate material as had been successfully done many times before. Instead the die was built with the two materials printed side by side-410SS on the side that would be the working surface of the die and mild steel on what would be the back/foundation of the die. This led to greater difficulties in the build and an increased number of defects in the part, though none were sufficient to prevent the stamping die from producing perfectly useable commercial parts. The die was also too thin to use ribbing on the back for lightweighting. The degree of weight savings did not justify the increased print time due to print complexity or the increased post machining time. A larger deeper die will provide more serious justification for AM production.

\subsection{IMPACTS}

This Phase 1 effort with Whirlpool Corporation proved valuable in several ways. The printing stamping die was successfully tested and the parts produced were found to be satisfactory for use. The amount of material printed was substantially less than the billet that would have been required to produce the stamping die machining from a billet of tool steel. Finally, the nitriding process was successful in producing hardness levels beyond what is typically required for stamping dies. All of these demonstrated capabilities have the potential to impact US industry by providing flexible adaptable manufacturing of durable stamping dies.

\subsubsection{SUBJECT INVENTIONS}

No subject inventions resulted from this collabotation. 


\subsection{CONCLUSIONS}

The most important conclusion of this effort is that the design, printing, post machining, nitriding, and testing of the stamping die demonstrated that the process worked to produce a functional tool. Nitriding produced more than adequate die hardness. Less material was used to to print the pre-form needed for post machining than would have been required for a starting block of material due to the inherent printing of a near net shape part that requires less finish machining.

Several findings and lessons learned were noted as part of this work. The stamping die requested by Whirlpool for this project was quite thin. This made multi-material infill difficult; therefore separate sections of 410SS and mild steel were printed side by side. This is more difficult than printing an exterior of one material and an infill in another material. The stamping die was also too thin to allow for much weight savings. As a result, only a few pounds of material was saved from the traditionally manufactured die.

Whirlpool has expressed interest in a Phase 2 for this technical collaboration. Whirlpool would need to find a good candidate for a large stamping tool that would take better advantage of the capabilities of AM, in particular, light weighting of the stamping die. While the nitriding was completely successful and does have useful application for future stamping dies, the nitriding process did require additional time and cost for die fabrication. Whirlpool would like to wait on a Phase 2 effort until we have developed the capability to print tool steel or tool steel equivalent materials (such as maraging $350)$.

\section{WHIRLPOOL CORPORATION BACKGROUND}

Whirlpool Corporation (NYSE: WHR) is the leading major appliance manufacturer in the world, with approximately $\$ 20$ billion in annual sales, 77,000 employees and 59 manufacturing and technology research centers in 2019. The company markets Whirlpool, KitchenAid, Maytag, Consul, Brastemp, Amana, Bauknecht, JennAir, Indesit and other major brand names in nearly every country throughout the world. Additional information about the company can be found at whirlpoolcorp.com. 